\title{
Pertanggungjawaban Pidana Pelaku Tindak Pidana Eksploitasi Seksual Anak: Tinjauan Terhadap Peraturan Perundangan
}

\author{
Zulkifli Ismail $^{1}$, Melanie Pita Lestari ${ }^{2}$, Ahmad $^{3}$ \\ ${ }^{123}$ Fakultas Hukum, Universitas Bhayangkara Jakarta Raya \\ Email: zulkifli.ismail@dsn.ubharajaya.ac.id; melanie.pita@dsn.ubharajaya.ac.id; \\ ahmad@dsn.ubharajaya.ac.id
}

Article info

Received: Sep 12,2021 Revised: Oct 24, $2021 \quad$ Accepted: Nop 22, $2021 \quad$ Published: Dec 9, 2021

DOI: https://doi.org/10.31599/krtha.v15i2.754

Keywords : Law Enforcement, Perpetrator, The crime of sexual exploitation of children

Abstract : The crime of sexual exploitation of children is a crime that never subsides even though the times are developing, as well as technology and human thought patterns have progressed. All criminal practices that result in degrading and threaten the physical and psychosocial integrity of children are included in the commercial sexual exploitation of children. The main issues that will be discussed in this study are how the form of the crime of child sexual exploitation and how the criminal responsibility of the perpetrators of the crime of sexual exploitation of children in terms of the existing laws and regulations in Indonesia. This study aims to identify and describe the forms of criminal acts of sexual exploitation of children and how the forms of criminal liability forperpetrators of crimes of child sexual exploitation as stated in the legislation. This study uses a normative juridical research method using a statutory approach. Based on the analysis conducted, it is known that Indonesia does not yet have legislation that specifically regulates this crime, so that in the future it is hoped that there will be a legislation that can specifically accommodate this crime.

Kata kunci : Penegakan Hukum, Pelaku, Tindak Pidana Eksploitasi Seksual Anak

Abstrak : Tindak pidana eksploitasi seksual anak merupakan sebuah kejahatan yang tidak pernah surut meskipun zaman semakin berkembang, serta tekonologi dan pola pikir manusia pun telah mengalami kemajuan. Semua praktek kriminal yang berakibat merendahkan dan mengancam integritas fisik serta psikososial anak termasuk dalam eksploitasi seksual komersial anak. Pokok permasalahan yang akan dibahas dalam penelitian ini adalah bagaimana bentuk dari tindak pidana eksploitasi seksual anak serta bagaimana pertanggungjawaban pidana pelaku tindak pidana eksploitasi seksual anak ditinjau dari peraturan perundangan yang ada di Indonesia. Penelitian ini bertujuan untuk mengetahui dan mendeskripsikan bentuk-bentuk tindak pidana eksploitasi seksual anak dan bagaimana bentuk pertanggungjawaban pidana pelaku tindak pidana eksploitasi seksual anak sebagaimana tercantum dalam peraturan perundang-undangan. Penelitian ini menggunakan metode penelitian yuridis normatif dengan menggunakan pendekatan perundang-undangan. Berdasarkan analisis yang dilakukan, diketahui bahwa Indonesia belum memiliki peraturan perundangan yang secara spesifik mengatur mengenai tindak pidana ini, sehingga ke depannya diharapkan akan ada 
sebuah peraturan perundangan yang dapat mengakomodir secara spesifik mengenai tindak pidana ini.

\section{PENDAHULUAN}

Dalam diri anak melekat harkat dan martabat manusia seutuhnya sehingga seorang anak berhak mendapatkan kesempatan untuk tumbuh dan berkembang baik secara fisik, mental maupun sosial, serta berhak atas perlindungan dan upaya untuk mewujudkan kesejahteraan anak serta mendapatkan pemenuhan atas hak-haknya. ${ }^{1}$ Dalam upaya memberikan jaminan atas pemenuhan hak anak dan memberikan perlindungan terhadap seluruh anak Indonesia, Pemerintah Indonesia telah meratifikasi Konvensi Hak Anak (KHA) melalui Keputusan Presiden Nomor 36 Tahun 1990 Tentang Pengesahan Konvensi Tentang Hak-Hak Anak. Pada pembukaan Konvensi Hak Anak disebutkan bahwa anak dikarenakan alasan ketidakdewasaan fisik dan jiwanya, membutuhkan perlindungan dan pengasuhan khusus termasuk perlindungan hukum yang tepat baik sebelum dan juga sesudah kelahirannya. ${ }^{2}$

Sebagai langkah nyata kelanjutan komitmen pemerintah dalam hal perlindungan terhadap anak, maka lahirlah Undang-Undang Nomor 23 Tahun 2002 tentang Perlindungan Anak, yang kemudian undang-undang ini telah direvisi sebanyak dua kali menjadi Undang-Undang Nomor 35 Tahun 2014 Tentang Perubahan Atas UndangUndang Nomor 23 Tahun 2002 Tentang Perlindungan Anak dan Undang-Undang Nomor 17 Tahun 2016 Tentang Perubahan Kedua Atas Undang-Undang Nomor 23 Tahun 2002 Tentang Perlindungan Anak. Pengertian anak sebagaimana dimaksud dalam Pasal 1 ayat (1) Undang-Undang Nomor 23 Tahun 2002 tentang Perlindungan Anak adalah seseorang yang belum berusia 18 (delapan belas) tahun, termasuk anak yang masih dalam kandungan. Selanjutnya, Pasal 1 ayat (12) Undang-Undang Nomor 23 Tahun 2002 disebutkan bahwa pada diri setiap anak yang dilabirkan melekat hak-hak yang merupakan bagian dari Hak. Asasi Manusia yang wajib dijamin, dilindungi dan dipenubi oleh orangtua, keluarga, masyarakat, negara, pemerintah dan pemerintah daerah.

Ketidakberdayaan anak yang disebabkan oleh ketidakdewasaan baik secara fisik maupun jiwa menyebabkan anak sangat mudah untuk menjadi korban eksploitasi. ${ }^{3}$ Salah satu eksploitasi yang sering terjadi pada anak-anak adalah eksploitasi seksual untuk tujuan

\footnotetext{
${ }^{1}$ I Dewa Made Suartha, Laporan Akbir Pengkajian Hukum Lembaga Penempatan Anak Sementara, Jakarta: Kementerian Hukum dan HAM Republik Indonesia, 2013, hlm. 1

${ }^{2}$ Ibid.

3 Aidy, W. R. (2020). Perlindungan Hukum Terhadap Anak Yang Berkonflik Dengan Hukum. Jurnal Hukum Sasana, 5(1). https://doi.org/10.31599/sasana.v5i1.90
} 
komersial. ${ }^{4}$ Eksploitasi seksual komersial anak mencakup praktek-praktek kriminal yang merendahkan dan mengancam integritas fisik dan psikososial anak. Eksploitasi Seksual Komersial Anak pertama kali diidentifikasi dalam Deklarasi dan Agenda Aksi untuk Menentang Eksploitasi Seksual Komersial Anak. ${ }^{5}$ Dalam deklarasi tersebut diidentifikasikan bahwa eksploitasi seksual komersial anak sebagai sebuah pelanggaran mendasar terhadap hak-hak anak. Pelanggaran tersebut dapat berupa kekerasan seksual oleh orang dewasa dan pemberian imbalan dalam bentuk uang tunai atau barang terhadap anak atau orang ketiga. ${ }^{6}$ Anak tersebut diperlakukan sebagai sebuah obyek baik secara seksual maupun komersial. Bentuk pemaksaan dan kekerasan terhadap anak, dan mengarah pada bentuk-bentuk kerja paksa serta perbudakan modern dapat dikategorikan sebagai eksploitasi seksual komersial anak. ${ }^{7}$

Bentuk utama dan yang memiliki kaitan erat dengan eksploitasi seksual komersial anak adalah pelacuran anak, pornografi anak dan perdagangan anak untuk tujuan seksual. Selain itu ada pula bentuk eksploitasi seksual anak yaitu pariwisata seks anak; dan dalam beberapa kasus adalah perkawinan anak. Perbudakan di dalam rumah atau kerja ijon ${ }^{8}$ merupakan suatu bentuk terselubung dari eksploitasi anak di mana seorang anak dikontrak untuk bekerja akan tetapi majikan percaya bahwa anak tersebut juga dapat dimanfaatkan untuk tujuan-tujuan seksual.

Tindak pidana eksploitasi sesual komersial anak terjadi karena adanya permintaan yang menjadi faktor pencetus. Oleh karena itu pencegahan dan penjatuhan hukuman kriminal menjadi penting, namun dalam setiap upaya untuk mengakhiri tindakan eksploitasi seksual komersial anak juga perlu memperhatikan upaya untuk menentang semua tingkah laku, keyakinan dan sikap yang mendukung dan melestarikan permintaan ini. $^{9}$

4 Al Adawiah, R. (2019). Child Abuse Dan Keamanan Lingkungan Anak Dalam Menyongsong Bonus Demografi 2025-2030. Krtha Bhayangkara, 13(1). https://doi.org/10.31599/krtha.v13i1.13

${ }^{5}$ Deklarasi dan Agenda Aksi telah diadopsi oleh 122 pemerintah pada pelaksanaan Kongres Dunia Pertama Untuk Menentang Eksploitasi Seksual Komersial Anak di Stokholm, Swedia, pada tahun 1996. Sampai dengan tahun 2006 sudah ada 161 negara yang mengadopsi Deklarasi dan Agenda Aksi tersebut

$6 \quad$ http://icjr.or.id/wp-content/uploads/2017/03/Penanganan-Kasus-Eska-di-Indonesia.pdf diakses pada tanggal 2 Agustus 2021

${ }^{7}$ Ibid.

${ }^{8}$ Arti ijon dalam Kamus Besar Bahasa Indonesia adalah (1) pembelian padi dan sebagainya sebelum matang dan diambil oleh pembeli setelah matang. (2) Kredit yang diberikan kepada petani, nelayan atau pengusaha kecil yang pembayarannya dilakukan dengan hasil panen atau produksi berdasarkan harga jual yang rendah.

http://kbbi.web.id.ijon diakses pada tanggal 12 Oktober 2021

sementara Kerja Ijon memiliki arti adalah cara seseorang untuk bekerja demi melunasi utang yang dimilikinya http://brainly.co.id diakses pada tanggal 12 Oktober 2021

9 Putri, A. H., \& Irsan, K. (2019). Penanganan Polisi Terhadap Kasus Perdagangan Perempuan Dan Anak Di Kalimantan Dan Jawa. Krtha Bhayangkara, 13(1). https://doi.org/10.31599/krtha.v13i1.20 
Berdasarkan latar belakang di atas, maka permasalahan yang akan dibahas dalam penulisan ini adalah: Bagaimanakah bentuk-bentuk tindak pidana eksploitasi seksual anak? Bagaimanakah penegakan hukum terhadap pelaku tindak pidana eksploitasi seksual komersial anak?

\section{II.METODE PENELITIAN}

Metode penelitian yang digunakan dalam penelitian ini adalah metode penelitian yuridis normatif, dengan menggunakan pendekatan perundangan-undangan. Pendekatan perundang-undangan dilakukan dengan menelaah semua peraturan perundangan yang bersangkutan dengan permasalahan yang dibahas dalam penelitian ini.

\section{PEMBAHASAN}

\section{Pengertian dan Bentuk Tindak Pidana Eksploitasi Seksual Anak}

Salah satu tindak pidana yang saat ini sedang berkembang adalah tindak pidana eksploitasi seksual anak (TPESA). Menurut ECPAT, eksploitasi seksual anak adalah sebuah pelanggaran mendasar terhadap hak asasi anak yang terdiri dari kekerasan seksual oleh orang dewasa dan pemberian imbalan uang atau sesuatu yang dinilai dengan uang di mana anak dijadikan obyek seks dan obyek komersial. ${ }^{10}$ Unsur-unsur yang termasuk dalam tindak eksploitasi seksual anak pun bermacam, mulai dari membeli, menawarkan, memperoleh, memproduksi, memindahtangankan, menyediakan, dan lain sebagainya. Bentuk dari tindak pidana ini adalah prostitusi anak, pornografi anak, perdagangan anak untuk tujuan seksual pariwisata seks anak dan perkawinan anak

\section{1) Prostitusi Anak}

Prostitusi anak merupakan sebuah tindakan menawarkan pelayanan atau pelayanan langsung seorang anak untuk melakukan tindakan seksual demi mendapatkan uang atau imbalan; ${ }^{11}$ Ketika seseorang mengambil keuntungan dari sebuah kesepakatan komersial di mana seorang anak disiapkan untuk sebuah tujuanseksual, maka terjadilah prostitusi anak. Kesepakatan tersebut dapat terjadi melalui jasa seorang perantara atau pelaku eksploitasi melakukannya secara langsung dengan anak tersebut.

Faktor yang menyebabkan seorang anak dapat terlibat dalam prostitusi anak adalah pemenuhan kebutuhan dasar seperti makanan, tempat tinggal, keamanan atau bantuan

${ }^{10}$ https://www.slideshare.net/ecpatindonesia/faq-bahasa-2008 diakses pada tanggal 2 Agustus

${ }^{11}$ Koalisi Nasional Penghapusan Eksploitasi Seksual Komersial Anak, Eksploitasi Seksual Komersial Anak di Indonesi, Medan, 2008, hlm. 6 
untuk mendapatkan nilai yang tinggi di sekolah atau bahkan uang ekstra untuk membeli barang-barang. Pemenuhan atas kebutuhan dasar atau membeli barang-barang konsumtif sebenarnya bukan merupakan pilihan bagi anak-anak, namun mereka terdorong oleh situasi, struktur sosial dan para pelaku ke dalam situasi di mana orang dewasa memanfaatkan kelemahan mereka sehingga dapat terjadi ekploitasi serta kekerasan seksual terhadap anak.

Penyebutan pelacur anak atau pekerja seks anak mengisyaratkan bahwa seorang anak seolah-olah memilih hal tersebut sebagai sebuah pekerjaan atau profesi. Persepsi ini tidaklah benar, karena pada kenyataannya pelacuran anak diciptakan oleh orang-orang dewasa melalui permintaan mereka atas anak-anak untuk dijadikan sebagai obyek seks, penyalahgunaan kekuasaan dan keinginan mereka untuk mengambil keuntungan sedangkan anak-anak tersebut hanyalah korban-korban kekerasan. Eksploitasi seksual komersial anak melalui pelacuran merupakan masalah global dan seringkali terkait erat dengan pornografi anak dan perdagangan anak untuk tujuan-tujuan seksual. Permintaan untuk melakukan hubungan seks dengan anak-anak bisa datang dari para pelaku eksploitasi yang datang dari dalam negeri maupun luar negeri.

\section{2) Pornografi Anak}

Semua pertunjukan yang dilakukan dengan cara apapun dan melibatkan anak dalam aktivitas seksual secara nyata atau yang menampilkan bagian tubuh anak demi tujuantujuan seksual dapat dikategorikan sebagai pornografi anak. ${ }^{12}$ Bentuk pornografi anak dapat berupa foto, pertunjukan visual dan audio serta tulisan. Penyebarannya dapat dilakukan melalui majalah, buku, gambar, film, kaset video, handphone serta disket atau file komputer. Secara umum, ada dua kategori pornografi, yaitu:

- Pornografi yang tidak eksplisit secara seksual tetapi mengandung gambar anak-anak yang telanjang dan menggairahkan;

- Pornografi yang menyajikan gambar anak-anak yang terlibat dalam kegiatan seksual. Penggunaan gambar anak dalam kedua kategori tersebut adalah bentuk dari eksploitasi seksual. Dalam tindak pidana pornografi anak, ada berbagai cara untuk mengeksploitasi anak-anak, yaitu:

(1) Pertama, Anak-anak dapat ditipu atau dipaksa untuk melakukan tindakan seksual untuk pembuatan bahan-bahan pornografi; atau dalam pengeksploitasian seorang 
anak secara seksual, pengambilan gambar dari anak dilakukan tanpa sepengetahuan anak dan kemudian gambar-gambar ini disebarkan, dijual atau diperdagangkan.

(2) Kedua, para penikmat pornografi anak akan terus mengeksploitasi anak-anak ini. Adanya permintaan dari para penikmat pornografi inilah yang menjadi pemicu dalam pembuatan bahan-bahan porno;

(3) Ketiga, anak-anak yang dimanfaatkan dalam pembuatan produk pornografi biasanya diancam, dipaksa atau diperas oleh para pembuat bahan pornografi dengan menggunakan produk-produk yang telah ada.

Ketika anak-anak yang dieksploitasi melalui gambar-gambar dalam pornografi tersebut dapat diidentifikasi seringkali ditemukan bahwa para pelaku eksploitasi tersebut biasanya diketahui sebagai anggota atau teman keluarga anak tersebut atau orang yang memberi pengasuhan atau perwalian bagi anak. Demikian pula terhadap anak-anak yang tinggal atau banyak menghabiskan waktu mereka di jalanan, anak-anak yang sudah dipaksa masuk ke dalam pelacuran dan anak-anak korban perdagangan juga rentan untuk dimanfaatkan dalam pembuatan pornografi. ${ }^{13}$

Tujuan pemanfaatan pornografi anak yang paling jelas adalah untuk menimbulkan gairah dan kepuasan seksual, namun seperti biasanya pornografi anak juga dipergunakan untuk membenarkan tingkah laku dan keyakinan-keyakinan tertentu sebagai sesuatu yang normal, mengabadikan masa remaja seorang anak dalam bentuk foto pada usia yang diinginkan, memberikan kredibilitas di antara orang-orang yang tertarik untuk menyalahgunakan anak, mendapatkan izin masuk ke dalam klub-klub pribadi dan untuk memperoleh keuntungan. Pornografi anak baik itu dalam bentuk gambar-gambar anak yang nyata atau eksplisit selalu berhasil menuai permintaan yang melibatkan eksploitasi dan kekerasan seksual terhadap anak dan seringkali pornografi anak ini terkait dengan pelacuran anak, pariwisata seks anak dan perdagangan anak untuk tujuan-tujuan seksual.

Penggunaan teknologi informasi dan internet saat ini menjadi sarana untuk membuat dan menyebarkan pornografi anak. Kemajuan teknologi dan meluasnya fasilitas internet memberikan lebih banyak kesempatan bagi para pelaku eksploitasi anak dan pembuat pornografi anak. Kemajuan teknologi ini juga memfasilitasi kekerasan seksual terhadap anak yang terorganisir dengan jaringan para pembeli komersial, wisatawan seks, pedofil, dan pelaku perdagangan.

${ }^{13}$ M. Taylor and E. Quayle. Child Pornography: An Internet Crime. Hove and New York: BrunnerRoutledge, 2003 
Dalam pembuatan pornografi anak, dikenal istilah morphing, yaitu penggunaan software grafik digital memudahkan seseorang untuk menggabungkan beberapa gambar menjadi satu gambar atau mengubah sebuah gambar untuk menciptakan sebuah gambar baru. Melalui tehnik morphing ini, gambar-gambar yang aslinya bukan gambar porno dapat dibuat seperti gambar porno dari "anak-anak asli” tersebut. Selain itu, juga gambargambar porno anak dapat diciptakan secara virtual. Dalam hal ini dapat terlihat hubungan antara pornografi anak dengan kekerasan seksual yang sebenarnya sangat jelas terlihat, karena keaslian gambar anak tidak memiliki pengaruh terhadap keinginan untuk melakukan hubungan seks dengan anak-anak.

Para pelaku eksploitasi seks anak menggunakan internet untuk mendapatkan akses terhadap pornografi anak dan anak-anak secara langsung. Para pembuat pornografi anak menggunakan network sharing file, newsgroups, system peer2peer dan teknologi-teknologi lain untuk bertukar dan menjual pornografi anak, dan para pelaku eksploitasi seks anak menggunakan hand phone dan ruang chatting serta tempat-tempat sosial online lain untuk memikat anak-anak dengan maksud untuk menyalahgunakan dan mengeksploitasi mereka. Penyebaran pornografi anak secara global melalui internet tanpa adanya payung hukum untuk melindungi anak-anak membuat para penegak hukum nasional kesulitan untuk menghukum para pelaku. Dikarenakan internet tidak dibatasi oleh batas-batas negara, maka harmonisasi perundang-undangan, kerjasama polisi internasional dan tanggung jawab industri IT dibutuhkan untuk menangani masalah tersebut.

\section{3) Perdagangan Anak untuk Tujuan Seksual}

Proses perekrutan, pemindahtanganan atau penampungan dan penerimaan anak untuk tujuan eksploitasi seksual dikategorikan sebagai perdagangan anak untuk tujuan seksual. ${ }^{14}$ Menurut Pelapor Khusus untuk Komisi Hak-Hak Asasi Manusia tentang perdagangan anak, pelacuran anak dan pornografi anak, definisi perdagangan anak adalah sebagai berikut:

"Perdagangan atau trafiking adalah semua perbuatan yang melibatkan perekrutan atau pengiriman orang di dalam maupun ke luar negeri dengan penipuan, kekerasan atau paksaan, jeratan butang atau pemalsuan dengan tujuan untuk menempatkan orang tersebut dalam situasisituasi kekerasan atau eksploitasi seperti pelacuran dengan paksaan, praktek-praktek yang serupa dengan perbudakan, penyiksaan atau kekejaman yang ekstrim, pekerjaan dengan gaji yang rendah atau pekerjaan-pekerjaan rumah tangga yang bersifat eksploitatif." 
Perdagangan manusia merupakan sebuah topik yang mendapat perhatian global dalam beberapa tahun belakangan ini. Hal ini disebabkan oleh perbatasan yang lemah dan teknologi komunikasi yang semakin canggih. Ruang lingkup perdagangan manusia telah semakin meluas secara transnasional dan memberikan keuntungan yang sangat besar. Orang yang menjadi korban perdagangan manusia, khususnya anak-anak, dapat diperjualbelikan sampai beberapa kali. Para korban perdagangan manusia merupakan komoditas dalam sebuah bisnis internasional yang menghasilkan keuntungan besar.

Kondisi anak yang masih belum mampu untuk memberikan izin atas eksploitasi seksual, perburuhan, transplantasi atau pemindahan organ-organ tubuh dan adopsi ilegal menyebabkan perdagangan anak dapat terjadi tanpa atau dengan menggunakan paksaan, kekerasan atau pemalsuan, ${ }^{15}$ namun semua anak korban trafiking telah dibuat sangat rentan terhadap kekerasan dan eksploitasi seksual karena mereka dipindahkan dari struktur-struktur pendukung yang sudah dikenal seperti keluarga dan lingkungan mereka. Aksi untuk memerangi perdagangan anak harus memperhatikan kondisi-kondisi yang membuat anak-anak rentan dan menghukum para pelaku.

Praktek perdagangan anak yang tersembunyi dan sulit untuk diperkirakan menyebabkan jumlah anak yang telah diperdagangkan tidak dapat diperkirakan dengan pasti. Perdagangan anak dapat terjadi baik di dalam maupun di luar negeri. Di dalam negeri, bentuk perdagangan anak terjadi di daerah-daerah pedesaan ke perkotaan di mana biasanya anak-anak dikirimkan untuk menjadi pekerja anak baik dalam sektor rumah tangga maupun pekerja anak di pabrik. Pada perdagangan internasional, para pelaku lebih diuntungkan karena mereka dapat menyembunyikan para korban dalam sebuah lingkungan asing. Anak-anak menjadi sangat rentan dalam perlindungan hukum dikarenakan mereka telah masuk secara illegal, serta mereka pun tidak mengenal budaya dan bahasa dari negara tersebut.

Anak-anak yang telah diperdagangkan ke luar negeri dapat terus diperdagangkan di dalam negara tersebut dengan tujuan untuk menghindari pendeteksian oleh pihak berwenang. Perdagangan orang antar negara dapat dikategorikan berdasarkan negara asal atau pengirim, negara tujuan dan negara transit (sebuah tempat yang dipergunakan untuk memasuki negara atau wilayah lain). Beberapa negara dapat masuk atau digolongkan ke dalam ketiga kategori ini, misalnya: ${ }^{16}$ Guatemala. Guatemala dapat dianggap sebagai negara asal, karena anak-anak ini telah diperdagangkan ke Meksiko atau Amerika Serikat.

${ }^{15}$ ECPAT Internasional, Tanya Jawab tentang Eksploitasi Seksual Komersial Anak, 2001, hlm. 11

${ }^{16}$ Ibid 
Guatemala juga merupakan negara tujuan bagi sebagian anak-anak dari El Savador, Honduras dan Nikaragua; dan juga menjadi negara transit untuk anak-anak dari negara tetangga Amerika Tengah yang diperdagangkan ke Amerika Serikat. Rute perdagangan berubah-ubah menyesuaikan pada situasi lokal serta faktor-faktor persedian dan permintaan.

\section{4) Pariwisata Seks Anak}

Pariwisata seks anak adalah sebuah bentuk eksploitasi seksual komersial anak yang dilakukan oleh orang-orang yang melakukan perjalanan dari suatu tempat ke tempat lain, dan di tempat tujuan mereka berhubungan seks dengan anak. Dalam kegiatan pariwisata seks anak seringkali melibatkan penggunaan jasa dari berbagai layanan akomodasi, transportasi dan layanan-layanan pariwisata yang dapat memfasilitasi kontak dengan anakanak dan memungkinkan pelaku untuk tetap tidak terlihat di dalam masyarakat dan lingkungan sekitar. ${ }^{17}$ Perbuatan yang tercakup dalam pariwisata Seks Anak adalah pemberian uang, pakaian, makanan atau bentuk kebaikan lain kepada seorang anak atau pihak ketiga untuk melakukan hubungan seksual. Tindak Pariwisata Seks Anak terjadi di berbagai tempat, mulai dari lokalisasi-lokalisasi di daerah pelacuran sampai ke pantaipantai atau hotel-hotel berbintang lima baik di daerah-daerah perkotaan, pedesaan maupun pesisir pantai.

\section{5) Perkawinan Anak}

Perkawinan anak adalah perkawinan yang melibatkan anak dan remaja usia di bawah 18 tahun. Ketika dalam sebuah perkawinan yang melibat anak, seorang anak diterima dan dimanfaatkan untuk tujuan-tujuan seksual demi mendapatkan barang atau bayaran dalam bentuk uang atau jasa, maka perkawinan anak dapat dianggap sebagai sebuah bentuk Eksploitasi Seksual Komersial Anak. ${ }^{18}$ Pernikahan dini dikategorikan dapat mengancam hak-hak asasi manusia seorang anak, termasuk hak mereka atas pendidikan, kesehatan yang layak dan kebebasan berekspresi. Dalam banyak kasus, ketika seorang anak di bawah umur menikah maka ia dapat kehilangan status mereka sebagai seorang "anak" dan perlindungan terkait yang berlaku secara nasional, dan seringkali perkawinan tersebut kadang tidak dimaksudkan untuk sebuah kebersamaan yang permanen. Di beberapa negara, istilah mut'ah atau kawin kontrak merupakan hal yang mungkin dilakukan melalui

${ }^{17}$ Koalisi Penghapusan Eksploitasi Seksual Komersial Anak, Memerangi Pariwisata Sex Anak: Tanya \& Jawab, Medan, 2008, hlm. 6

${ }^{18}$ ECPAT Internasional, Op. Cit., hlm. 15 
sebuah kontrak nikah jangka pendek yang dikenal dengan siqueh di Timur Tengah dan Afrika Utara. Kawin kontrak ditambah dengan usia legal perkawinan yang rendah memungkinkan orang untuk mengelak dari tindakan illegal pelacuran anak. Tradisi perkawinan anak terus berlanjut dikarena beberapa alasan berikut, yaitu: ${ }^{19}$

(1) Jika menikahi pasangan yang lebih muda maka akan terhindar dari kemungkinan terinfeksi HIV.

(2) Jika kemiskinan sangat serius, pernikahan dini juga dipandang sebagai sebuah strategi yang tepat untuk bertahan hidup secara ekonomi.

(3) Pernikahan dini kadang dianggap sebagai sebuah cara untuk menjamin perlindungan terhadap anak-anak perempuan.

Sebagian anak dipaksa untuk menikah oleh orangtua atau keluarga mereka sedangkan anak-anak masih terlalu muda agar dianggap keputusan yang dibuat adalah benar benar, maka izin diberikan oleh orang lain atas nama anak tersebut sementara anak tersebut tidak memiliki kesempatan untuk menggunakan haknya untuk memilih, sehingga dapat dikatakan bahwa dalam kasus-kasus seperti ini, pernikahan dini dianggap sebagai suatu bentuk kawin paksa.

Banyak anak perempuan yang dipaksa untuk cepat-cepat menikah mengalami kekerasan yang tiada akhir di dalam rumah tangga mereka. Di samping itu, pernikahan dini sering berkaitan dengan penelantaran istri dan penjerumusan anak-anak perempuan muda ke dalam kemiskinan yang luar biasa serta peningkatan resiko bahwa mereka akan dipaksa untuk memasuki industri perdagangan seks agar dapat bertahan hidup.

\section{Faktor-Faktor Penyebab Anak Sebagai Korban Tindak Pidana Eksploitasi Seksual Anak}

Tindak eksploitasi seksual komersial anak mencakup perbuatan-perbuatan yang seringkali berasal dari keyakinan budaya, globalisasi serta teknologi baru memberikan gambaran atas sejumlah tantangan yang berbeda dan selalu berubah-ubah. ${ }^{20}$ Permintaan akan anak-anak sebagai pasangan seks untuk tujuan apapun mendorong ke arah eksploitasi seksual komersial anak. Meskipun demikian, terdapat faktor-faktor yang kompleks yang membuat anak menjadi rentan serta membentuk kekuatan-kekuatan dan menciptakan situasi dan kondisi yang memungkinkan anak-anak untuk dieksploitasi secara seksual komersial.

19 Ibid

20 Analysis of the Situation of Sexual Exploitation of Children in the Eastern and Southern Africa Region. UNICEF. 2001 
Berikut ini adalah faktor-faktor dan kekuatan-kekuatan yang menciptakan situasi dan kondisi yang memungkinkan anak untuk dieksploitasi secara seksual komersial

\section{1) Penerimaan Masyarakat}

Konsep-konsep mengenai masa kanak-kanak, seksualitas anak, perkembangan anak, fasilitas pribadi dan umum yang terkait dengan tingkah laku seksual, kekuasaan laki-laki/perempuan dan peranan-peranan seksual dan moralitas terkait dengan seksualitas adalah konstruk sosial yang secara langsung maupun tidak langsung memfasilitasi dan/atau menyebabkan terjadinya ESKA. Elemen-elemen seperti itu sering dipahami sebagai sesuatu yang "kodrati" dan sering tidak dipertanyakan maupun ditentang, khususnya ketika elemen-elemen tersebut terkait dengan anak-anak. Banyak dari elemen ini yang digeneralisasikan pada tingkat global sedangkan elemen-elemen lainnya mewakili dinamika lokal yang berbeda-beda.

\section{2) Tradisi dan Adat-Istiadat yang Merugikan}

Sejumlah tradisi dan adat-istiadat membuat anak rentan terhadap eksploitasi seksual. Di beberapa negara, eksploitasi seksual terhadap anak sangat disamarkan sebagai praktek keagamaan, contohnya: di Ghana, penyerahan anak-anak perempuan ke tempat pemujaan lokal dilakukan untuk menebus tindak kejahatan yang dituduhkan telah dilakukan oleh seorang anggota keluarga anak perempuan tersebut. Dalam praktek tradisional yang dikenal dengan nama Trokosi ini, seorang anak perempuan akan menjadi milik pendeta tempat pemujaan tersebut yang dianggap mempunyai kekuatan magis dan harus memberikan layanan seksual serta melakukan pekerjaan-pekerjaan lain untuk sang pendeta.

\section{3) Diskriminasi/Kesukuan}

Suku-suku minoritas sering rentan terhadap kekuatan-kekuatan eksploitatif yang memanfaatkan rendahnya status resmi mereka atau pandangan yang merendahkan mereka. Hal ini membuat mereka beresiko diperdagangkan atau dipaksa masuk ke dalam eksploitasi seksual.

\section{4) Perilaku Seksual dan Mitos yang Tidak Bertanggung Jawab}

Banyak pria yang menilai bahwa pengambilan keperawanan seorang anak perempuan baik melalui mekanisme sosial pernikahan ataupun mekanisme lain adalah sebagai bukti dari kejantanan mereka. Di samping itu, ada berbagai pandangan yang salah atau mitos-mitos tentang melakukan hubungan seks dengan seseorang yang masih perawan atau dengan seorang anak. Di banyak negara di 
Asia dan Afrika, sebagian pria percaya bahwa melakukan hubungan seks dengan anak-anak perempuan yang masih muda (yang diperkirakan masih perawan atau masih memiliki pasangan seks yang sedikit) akan melindungi mereka dari terinfeksi HIV/AIDS dan penyakit-penyakit terkait lainnya ataupun menyembuhkan penyakit-penyakit tersebut, sedangkan yang lain percaya bahwa melakukan hubungan seks dengan seseorang yang masih perawan akan membuat mereka awet muda, meningkatkan kesuburan dan membuat mereka sehat, panjang umur, beruntung dan sukses dalam bisnis.

\section{5) Kemiskinan}

Walaupun dalam banyak kasus kemiskinan merupakan penyebab utama, akan tetapi kemiskinan sendiri tidak memberikan penjelasan yang cukup mengenai kerentanan seorang anak. Banyak anak dari keluarga-keluarga miskin yang selamat dari eksploitasi seksual dan banyak pula anak dan keluarga-keluarga kaya yang menjadi korban eksploitasi seksual. Kemiskinan menciptakan kondisi-kondisi yang dapat meningkatkan kerentanan seorang anak terhadap eksploitasi seksual dan membatasi peluang bagi para keluarga untuk memberikan lingkungan yang aman bagi anak tersebut untuk tumbuh dan berkembang.

\section{6) Kekerasan dalam Rumah Tangga Terhadap Anak dan Penelantaran}

Kekerasan seksual dan penelantaran yang sering dilakukan oleh orangtua, keluarga atau anggota masyarakat di mana anak tinggal membuat anak-anak rentan terhadap eksploitasi seksual tanpa mendapatkan perhatian dan perlindungan orang dewasa. Jika terpaksa harus meninggalkan rumah, anak-anak dapat lebih beresiko lagi karena tekanan teman sebaya, keputusasaan atau tekanan.

\section{7) Situasi-Situasi Gawat Darurat atau Bencana}

Kehancuran rutinitas-rutinitas tradisional, hilangnya berbagai struktur bantuan sosial dan pecahnya keluarga dapat terjadi selama situasi gawat darurat. Sayangnya, hubungan kekuasaan yang tidak seimbang dapat berkembang di antara mereka yang memberi dan mereka yang menerima dalam konteks emergensi dan anakanak yang telah menderita dan tanpa perlindungan ini dapat menjadi korban para penjahat atau orang-orang yang seharusnya memberi bantuan kemanusiaan kepada mereka.

\section{8) Situasi-Situasi Konflik}

Situasi-situasi darurat, kekacauan akibat pecahnya konflik, pelarian dan pemindahan dapat memisahkan anak-anak dari orangtua dan para pengasuh 
mereka. Anak-anak yang terpisah dari orangtua mereka secara khusus rentan dan beresiko terhadap kekerasan seksual atau eksploitasi.

\section{9) Tinggal dan Bekerja di Jalanan}

Anak jalanan dapat ditemukan di sebagian besar kota di seluruh dunia. Ketika berada di jalanan dan berada dalam lingkungan yang asing tanpa adanya perlindungan dan pengasuhan dari orangtua atau orang-orang dewasa lain, maka anak-anak secara khusus rentan dan mungkin terpaksa masuk ke dalam pelacuran agar dapat bertahan hidup.

\section{0) Konsumerisme}

Di banyak negara maju, banyak anak yang terdorong masuk ke dalam pelacuran, mereka bukan hanya anak-anak yang berasal dari kelas bawah yang mencoba lari dari kemiskinan tetapi juga anak-anak yang berasal dari kelas menengah yang menginginkan pendapatan yang lebih besar yang dapat mereka hamburhamburkan. Mereka terbujuk oleh tekanan teman sebaya atau iklan-iklan yang begitu hebat serta nilai yang diberikan oleh masyarakat pada produk-produk bermerek yang mahal atau barang-barang dan layanan-layanan mewah untuk menukarkan layanan seksual demi uang atau produk-produk status lainnya.

\section{1) Adopsi}

sebenarnya, adopsi merupakan sebuah langkah perlindungan permanen untuk anak-anak yang kehilangan keluarga dan harus menjadi hasil akhir dari proses yang dilakukan secara professional dan multidisipliner untuk menjamin ditegakkannya kepentingan terbaik seorang anak, namun dalam bentuk perdagangan, istilah “adopsi” dapat dijadikan topeng bagi pemindahan seorang anak dari satu orang kepada orang yang lain untuk tujuan eksploitasi seksual.

\section{2) Hukum yang Tidak Layak dan Korupsi}

Banyak negara yang kekurangan kerangka hukum yang komprehensif untuk mencegah tindak kriminal, mengelola upaya-upaya penyelidikan, menuntut para pelaku serta melindungi dan membantu anak-anak selama proses pemulihan mereka. Di samping itu, korupsi yang dilakukan oleh polisi dan para penegak hukum lainnya dapat menjadi hambatan utama dalam memerangi eksploitasi seksual komersial anak. Seperti semua tindakan illegal, kita juga merasa sulit untuk menentukan besaran masalah korupsi. Para pelaku perdagangan dapat menyuap penjaga perbatasan dan polisi akan menerima tawaran dari para pemilik lokalisasi untuk mendapatkan layanan gratis sebagai imbalan agar mereka tutup mulut. 


\section{3) Teknologi Informasi dan Komunikasi}

Penggunaan teknologi informasi dan komunikasi bagi anak dan remaja memiliki resiko yang sangat tinggi. Tanpa mereka sadari, anak-anak ini dijadikan sebagai subyek foto atau video yang dikirim melalui ruang maya (yber); atau mereka diiklankan secara online sebagai komoditas; dan/atau mereka terkena imbas oleh kekerasan dan bahaya-bahaya yang timbul dari interaksi-interaksi online yang dilakukan oleh orang lain, termasuk penggunaan pornografi.

Berikut ini adalah jenis-jenis kekerasan dan eksploitasi yang diakibatkan oleh teknologi informasi dan komunikasi:

- Pembuatan, penyebaran dan penggunaan bahan-bahan yang menggambarkan kekerasan seksual terhadap anak;

- Rayuan online atau grooming (upaya mendapatkan kepercayaan seorang anak untuk memikat mereka ke dalam sebuah situasi di mana mereka akan diperlakukan salah)

- Pemaparan terhadap bahan-bahan yang dapat menimbulkan resiko atau dampak buruk psikologis atau membawa pada resiko fisik.

- Pelecehan atau intimidasi, termasuk tindakan mempermainkan anak.

Faktor-faktor yang telah disebutkan di atas dapat kita klasifikasikan dalam dua kategori yaitu:

a. Faktor Pendorong

- Kondisi ekonomi khususnya kemiskinan di pedesaan yang diperberat oleh kebijakan pembangunan ekonomi dan penggerusan di sektor pertanian;

- Perpindahan penduduk dari desa ke kota dengan pertumbuhan pusatpusat industri di perkotaan.

- Ketidaksetaraan gender dan praktek-praktek diskriminasi;

- Tanggung jawab anak untuk mendukung keluarga;

○ Peningkatan konsumerisme

○ Disintegrasi keluarga

- Kemajuan teknologi dan informasi

b. Faktor Penarik

○ Jaringan kriminal yang mengorganisir industri seks dan merekrut anakanak;

- Praktek-praktek pekerja anak termasuk kerja paksa 
- Praktek-praktek tradisional dan budaya termasuk tuntutan keperawanan; praktek budaya di mana laki-laki pergi ke pelacuran; pola antar generasi dalam hal masuknya anak perempuan ke pelacuran;

- Berkembangnya beberapa daerah sebagai daerah tujuan wisata;

- Permintaan dari pekerja migran;

- Anak-anak yang terpapar pornografi.

\section{Dampak Eksploitasi Seksual Komersial Pada Anak-Anak}

Eksploitasi seksual komersial dalam bentuk apapun sangat membahayakan hakhak seorang anak untuk menikmati masa remaja mereka dan kemampuan mereka untuk hidup produktif, berharga dan bermartabat. Tindakan tersebut akan membawa dampakdampak yang serius sepanjang hidup bahkan mengancam nyawa dan jiwa anak sehubungan dengan perkembangan-perkembangan fisik, psikologis, spiritual, emosional dan sosial serta kesejahteraan. Walaupun dampaknya bervarasi berdasarkan pada situasi yang dihadapi anak dan tergantung pada berbagai faktor seperti tahap perkembangan dan sifat lamanya serta bentuk kekerasan, akan tetapi semua anak yang mengalami eksploitasi seksual dan komersial akan menderita berbagai dampak negatif.

Anak-anak yang mengalami eksploitasi secara seksual dan komersial sangat beresiko terjangkit HIV/AIDS dan mereka sepertinya tidak akan mendapatkan perawatan medis yang layak. Anak-anak juga sangat rentan terhadap kekerasan fisik. Anak-anak yang berusaha untuk melarikan diri atau melawan pelaku kekerasan tersebut dapat menderita luka berat atau bahkan dibunuh. Dampak-dampak psikologis dari eksploitasi seksual dan ancaman-ancaman yang dipergunakan biasanya akan membekas sepanjang sisa hidup mereka. Jika ada gambar-gambar dari kekerasan tersebut seperti foto, maka keberadaan gambar-gambar tersebut akan menjadi pengingat traumatis atas kekerasan itu.

Perawatan dan rehabilitasi bagi anak-anak korban eksploitasi seksual komersial merupakan sebuah proses yang sangat kompleks dan sulit. Anak-anak yang telah mengalami eksploitasi biasanya memiliki perasaan malu, rasa bersalah dan rendah diri. Sebagian anak tidak percaya bahwa mereka layak untuk diselamatkan, sedangkan sebagian yang lain menderita stigmatisasi atau perasaan bahwa mereka telah dikhianati oleh seseorang yang telah mereka percayai, lainnya mengalami mimpi buruk, tidak bisa tidur, putus asa dan depresi. Reaksi yang sama juga terjadi pada anak-anak korban penyiksaan. Untuk mengatasi hal ini, sebagian dari anak-anak tersebut berusaha untuk bunuh diri atau 
menyalahgunakan narkoba. Banyak di antara mereka yang merasa sulit untuk berhasil berintegrasi ke dalam masyarakat ketika mereka sudah dewasa.

\section{Pertanggungjawaban Pidana Pelaku Tindak Pidana Eksploitasi Seksual Anak}

Para pelaku kekerasan seksual terhadap anak berasal dari semua sisi kehidupan dan latar belakang sosial. Mereka dapat berprofesi sebagai apa saja dan berada di mana pun. Para pelaku ini bisa heteroseksual maupun homoseksual, dan terkadang pelaku kekerasan seksual terhadap anak ada juga pelaku wanita, walaupun sebagaian besar pelaku adalah laki-laki.

Penyebutan istilah "pedofil" kepada pelaku kekerasan seksual terhadap anak dianggap tidak tepat, karena istilah pedofil mengacu pada seseorang yang memiliki minat seksual khusus terhadap anak-anak yang belum puber. Sebagian pedofil mungkin tidak benar-benar melakukan tindakan berdasarkan pada fantasi-fantasi mereka, namun seseorang yang mengeksploitasi atau melakukan kekerasan seksual terhadap seorang anak mungkin melakukan hubungan seks dengan seorang anak semata-mata hanya karena mereka memang bisa melakukannya. Oleh karena itu, akan lebih tepat dan berguna jika menggunakan istilah "pelaku seks anak" untuk menggambarkan seseorang yang melakukan hubungan seks dengan seorang anak.

Para pelaku seks anak pada umumnya dapat dibagi ke dalam dua kategori, yaitu: pelaku situasional dan pelaku preferensial. Pelaku seks anak situasional tidak benar-benar memiliki pilihan seksual khusus pada anak tetapi mereka melakukan hubungan seks dengan anak-anak karena ada kesempatan. Para pelaku seperti itu dapat mengeksploitasi anak-anak karena mereka berada dalam situasi di mana mereka dapat mengakses atau mendapatkan seorang anak dengan mudah atau faktor-faktor tertentu yang memungkinkan mereka untuk menipu diri sendiri tentang usia atau izin anak untuk melakukan aktifitas seksual. Eksploitasi seksual terhadap anak dapat berupa tindakan yang dilakukan ketika sedang liburan atau hal tersebut dapat berkembang menjadi suatu kebiasaan melakukan kekerasan jangka panjang; Pelaku seks anak preferensial memiliki pilihan seksual yang jelas terhadap anak-anak. Jumlah mereka lebih sedikit jika dibandingkan dengan jumlah pelaku situasional tetapi mereka lebih berpotensi untuk melakukan kekerasan terhadap lebih banyak anak-anak daripada pelaku seks situasional karena hal tersebut memang sudah menjadi niat dan keinginan mereka. Berikut ini adalah pola tingkah laku mereka yang dapat diketahui: 
- Mereka merayu menggunakan kasih saying, perhatian atau hadiah untuk memikat anak-anak dan bersedia menghabiskan waktu yang lama untuk membujuk para korban mereka dengan tujuan mempersiapkan anak-anak itu untuk kekerasan tersebut. Mereka juga dapat menggunakan ancaman, pemerasan, dan kekerasan fisik agar kejahatan mereka tidak terbongkar;

- Para pelaku introvert menyukai anak-anak tetapi kurang memiliki kemampuan untuk berinteraksi dengan mereka. Mereka sangat jarang berkomunikasi dengan para korban dan cenderung untuk melakukan kekerasan terhadap anak-anak yang tidak dikenal ataupun anak-anak yang masing sangat muda;

- Ada namun tindak banyak adalah para pelaku sadistik, yaitu orang-orang yang selain memiliki ketertarikan seksual terhadap anak-anak juga mendapatkan kesenangan seksual dari tindakan yang menimbulkan rasa sakit pada korban. Pelaku jenis ini kemungkinan besar menggunakan paksaan untuk mendapatkan akses pada anak dan kemungkinan menculik atau membunuh korbannya.

Dalam berbagai situasi, batas-batas pengkategorian antara pelaku preferensial dan situasional memang tidak jelas. Sekelompok pelaku kekerasan lainnya memandang seks sebagai suatu cara untuk menunjukkan kekuasaan dan kontrol terhadap para korban mereka. Oleh karena itu, di beberapa wilayah di dunia ini pengeksploitasian pasangan muda dan lugu diterima secara luas sebagai sebuah indikator kejantanan. Hasil-hasil penelitian di Peru ${ }^{21}$ menunjukkan bahwa para pelaku eksploitasi yang dilaporkan, "merasa lebih muda" jika mereka melakukan hubungan seks dengan anak-anak perempuan yang masih muda. Penelitian ini menunjukkan adanya preferensi terhadap perempuan muda di antara para konsumen seks komersial yang dinyatakan secara luas sampai pada tingkatan di mana mereka dapat disebut sebagai pelaku preferensoal daripada pelaku situasional.

Sikap lain yang dikenal dari mereka yang diteliti adalah bahwa ketika seorang anak perempuan mencapai masa puber dan menunjukkan tanda-tanda perkembangan seksual, maka anak-anak tersebut secara seksual dianggap tersedia untuk laki-laki. Oleh karena itu, mereka tidak dianggap atau didefinisikan sebagai anak-anak dan dianggap tidak membutuhkan perlindungan. Meskipun para pelaku seks anak menciptakan permintaan untuk berhubungan seks dengan anak-anak namun sebenarnya banyak individu dan kelompok yang memberikan kontribusi terhadap eksploitasi seksual komersial mereka (anak), yang termasuk para individu dan kelompok ini adalah para anggota keluarga, tokoh masyarakat, sektor swasta ataupun jaringan kejahatan yang terorganisir.

${ }^{21}$ IOM Trafficking in Migrants Bulletin: Organized Crime Moves Into Trafficking. 1996 
KRTHA BHAYANGKARA | Volume 15 Number 2, December 2021

Penipuan merupakan sebuah hal yang sudah lazim terjadi walaupun sebagian orangtua diketahui sengaja menjual anak-anak mereka kepada para pemilik lokalisasi atau pelaku perdagangan. Kemiskinan merupakan salah satu alasan tetapi terdapat faktor-faktor lain seperti ketergantungan obat-obatan, niat untuk menyembunyikan kasus incest dalam keluarga, diskriminasi terbadap anak perempuan dan ketamakan akan harta benda.

Orang-orang yang dikenal oleh anak tersebut dapat bertindak atas nama agen untuk mendapatkan sedikit uang dan membujuk anak tersebut agar masuk ke dalam perdagangan seks atau merayu mereka agar pergi jauh dari rumah. Para tokoh masyarakat juga dapat terlibat baik secara langsung maupun tidak langsung jika mereka mengetahui para agen yang melakukan perekrutan di desa mereka tetapi mereka mengabaikannya untuk mendapatkan sebagian dari rejeki yang ditawarkan. Jaringan tindak kejahatan yang terorganisir juga turut ambil bagian dalam mendapatkan dan memberikan jalan bagi para gadis belia dan anak-anak yang rentan ke arah eksploitasi seksual komersial dan dalam mengekalkan eksploitasi seperti itu. Alasannya sudah jelas, yaitu keuntungan yang besar.

Indonesia masih belum memiliki pengaturan hukum spesifik yang dapat dikenakan kepada pelaku tindak pidana eksploitasi seksual anak, meskipun secara internasional sudah ada instrumen hukum yang mengatur mengenai tindak pidana ini, yaitu: Protokol Opsional Konvensi Hak Anak Tentang Penjualan Anak, Prostitusi Anak dan Pornografi Anak (Protokol OPSC). Oleh karena itu, ketika terjadi tindak pidana eksploitasi seksual anak masih digunakan beberapa instrumen nasional lainnya seperti:

- Undang-Undang Nomor 35 Tahun 2014 tentang Perlindungan Anak;

- Undang-Undang Nomor 23 Tahun 20024 tentang Penghapusan Kekerasan Dalam Rumah Tangga;

- Undang-Undang Nomor 11 Tahun 2008 tentang Informasi dan Transaksi Elektronik;

- Undang-Undang Nomor 21 Tahun 2007 tentang Pemberantasan Tindak Pidana Perdagangan Orang;

- Undang-Undang Nomor 39 Tahun 1999 tentang Hak Asasi Manusia; dan

- Undang-Undang Nomor 44 Tahun 2008 tentang Pornografi.

\section{(1) Hukum Internasional mengenai Tindak Pidana Eksploitasi Seksual Anak}

Hukum Internasional yang mengatur mengenai tindak pidana eksploitasi seksual anak adalah Protokol Opsional Konvensi Hak Anak Tentang Penjualan Anak, Prostitusi Anak dan Pornografi Anak (Protokol OPSC) 
Protokol Opsional Konvensi Hak-Hak Anak Mengenai Penjualan Anak, Prostitusi Anak, Dan Pornografi Anak (protocol to the convention on the right of the child on the sale of children, child prostitution, and child pornography) adalah suatu instrumen yang menetapkan hak-hak tambahan dan kewajiban-kewajiban dari Konvensi Hak-Hak Anak. Protokol Opsional merupakan bentuk komitmen negara-negara kepada dunia internasional untuk melarang bentuk-bentuk eksploitasi seksual anak meliputi perdagangan anak, pelacuran anak, dan pornografi anak yang telah disahkan oleh Majelis umum PBB pada tanggal 25 Mei 2000 dan kemudian Indonesia menandatangani Protokol ini pada tanggal 24 September 2001 dan meratifikasinya dalam Undang-Undang Nomor 12 Tahun 2012. Meskipun Indonesia telah meratifikasi Protokol Operasional ini, tidak semua unsur dari setiap kejahatan eksploitasi seksual anak yang secara jelas diatur dalam setiap pasal yang dibahas dalam konvensi ini, ditransformasikan dan diharmonisasikan dalam Undang-Undang yang sudah ada terkait dengan tindak pidana eksploitasi seksual anak.

Berdasarkan Pasal 2 dan Pasal 3 Protokol Opsional, definisi Penjualan Anak, Prostitusi Anak dan Pornografi Anak adalah sebagai berikut:

\begin{tabular}{|c|c|c|}
\hline $\begin{array}{l}\text { Jenis } \\
\text { Tindak } \\
\text { Pidana }\end{array}$ & $\begin{array}{l}\text { Pasal } 2 \\
\text { Protokol Opsional }\end{array}$ & $\begin{array}{l}\text { Pasal } 3 \\
\text { Protokol Opsional }\end{array}$ \\
\hline $\begin{array}{l}\text { Penjualan } \\
\text { anak }\end{array}$ & $\begin{array}{l}\text { Penjualan anak berarti setiap } \\
\text { tindakan atau transaksi di mana } \\
\text { seorang anak dipindahkan } \\
\text { kepada orang lain oleh siapapun } \\
\text { atau kelompok demi } \\
\text { keuntungan atau dalam bentuk } \\
\text { lain }\end{array}$ & $\begin{array}{l}\text { Menawarkan, mengantarkan atau } \\
\text { menerima anak dengan berbagai cara } \\
\text { untuk tujuan berikut: } \\
\text { - Eksploitasi seksual anak } \\
\text { - Mengambil organ tubuh anak } \\
\text { untuk suatu keuntungan } \\
\text { - Keterlibatan anak dalam kerja } \\
\text { paksa } \\
\text { Penculikan anak untuk adopsi }\end{array}$ \\
\hline $\begin{array}{l}\text { Prostitusi } \\
\text { anak }\end{array}$ & $\begin{array}{l}\text { Prostitusi anak berarti } \\
\text { menggunakan seorang anak } \\
\text { untuk aktifitas seksual demi } \\
\text { keuntungan atau dalam bentuk } \\
\text { lain }\end{array}$ & $\begin{array}{l}\text { Menawarkan, mendapatkan, dan } \\
\text { menyediakan anak untuk prostitusi. }\end{array}$ \\
\hline
\end{tabular}


KRTHA BHAYANGKARA | Volume 15 Number 2, December 2021

\begin{tabular}{llrlr}
\hline Pornografi & Pornografi anak & berarti & Memproduksi, & mengirimkan, \\
anak & pertunjukkan apapun atau & menyebarkan, & mengimpor, \\
& dengan cara apa saja yang & mengekspor, menawarkan, menjual \\
& melibatkan anak di dalam & atau memiliki untuk tujuan pornografi \\
& aktifitas seksual yang nyata atau anak. \\
& eksplisit atau yang menampilkan \\
& bagian tubuh anak demi tujuan \\
& seksual
\end{tabular}

(2) Peraturan Perundang-undangan Mengenai Tindak Pidana Eksploitasi Seksual Anak

Dalam peraturan perundangan yang dimiliki oleh bangsa Indonesia, pengaturan mengenai tindak pidana eksploitasi seksual anak terdapat dalam peraturan perundangan sebagai berikut:

a. Undang-Undang Nomor 35 Tahun 2014 tentang Perubahan Atas UndangUndang Nomor 23 Tahun 2002 tentang Perlindungan Anak

Dalam Undang-Undang ini tindak pidana eksploitasi seksual anak diatur dalam pasal:

\section{Pasal 76E}

Dalam undang-undang perlindungan anak Pasal 76E ini dijelaskan bahwa Setiap orang dilarang melakukan kekerasan atau ancaman kekerasan, memaksa, melakukan tipu muslihat, melakukan serangkaian kebohongan, atau membujuk anak untuk melakukan atau membiarkan dilakukan perbuatan cabul.

Ditambahkan dalam Pasal 82 bahwa Setiap orang yang melanggar ketentuan sebagaimana dimaksud dalam Pasal 76E dipidana dengan pidana penjara paling singkat 5 (lima) tabun dan paling lama 15 (lima belas) tabun dan denda paling banyak Rp.5.000.000.000,00 (lima milyar).

Apabila tindak pidana di Pasal 76E ini dilakukan oleh orangtua, wali, pengasuh anak, pendidik atau tenaga kependidikan maka pidananya ditambah 1/3 (sepertiga) dari ancaman pidana

\section{Pasal 76F}

Dalam Undang-Undang Perlindungan Anak, Pasal 76F ini menjelaskan bahwa setiap orang dilarang menempatkan, membiarkan, melakukan, menyurub melakukan, atau turut serta melakukan penculikan, penjualan, dan/ atau perdagangan anak. 
KRTHA BHAYANGKARA | Volume 15 Number 2, December 2021

Lebih lanjut dalam Pasal 83 dikemukakan bahwa Setiap orangyang melanggar ketentuan sebagaimana dimaksudkan dalam Pasal 76F dipidana dengan pidana penjara paling singkat 3 (tiga) tahun dan paling lama 15 (lima belas) tabun dan denda paling sedikit Rp. 60.000.000,00 (enam puluh juta rupiah) dan paling banyak R. 300.000.000,00 (tiga ratus juta rupiah)

\section{Pasal 76I}

Dalam Undang-Undang Perlindungan Anak Pasal 76I ini dijelaskan bahwa setiap orang dilarang menempatkan, membiarkan, melakukan, menyurub melakukan, atau turut serta melakukan eksploitasi secara ekonomi dan/ atau seksual terhadap anak.

Lebih lanjut dijelaskan dalam Pasal 88 bahwa setiap orang yang melanggar ketentuan sebagaimana dimaksud dalam Pasal 76I, dipidana dengan pidana penjara paling lama 10 (sepulub) tabun dan/atau denda paling banyak R. 200.000.000,00 (dua ratus juta rupiah).

\section{b. Undang-Undang Nomor 23 Tahun 2004 tentang Penghapusan Kekerasan dalam Rumah Tangga}

Tindak pidana eksploitasi seksual anak dalam Undang-Undang Penghapusan Kekerasan Dalam Rumah Tangga diatur dalam pasal:

\section{Pasal 47}

Dalam Undang-Undang Penghapusan Kekerasan Dalam Rumah Tangga dijelaskan bahwa setiap orang yang memaksa orang yang menetap dalam rumah tangganya melakukan hubungan seksual sebagaimana dimaksud dalam Pasal 8 huruf b dipidana dengan pidana penjara paling singkat 4 (empat) tabun dan pidana penjara paling lama 15 (lima belas) tabun atau denda paling sedikit Rp. 12.000.000,00 (dua belas juta rupiab) atau denda paling banyak Rp. 300.000.000,00 (tiga ratus juta rupiah).

Lebih lanjut disebutkan dalam Pasal 8 huruf b mengenai pemaksaan hubungan seksual terhadap salah seorang dalam lingkup rumah tangganya dengan orang lain untuk tujuan komersial dan/atau tujuan tertentu.

\section{c. Undang-Undang Nomor 11 Tahun 2008 tentang Informasi dan Transaksi Elektronik}

Dalam undang-undang ini, tindak pidana eksploitasi seksual anak diatur dalam pasal: 
KRTHA BHAYANGKARA | Volume 15 Number 2, December 2021

\section{Pasal 27 ayat (1) jo Pasal 52 ayat (1)}

Dalam Undang-Undang Informasi dan Transaksi Elektronik Pasal 27 ayat (1) dijelaskan bahwa setiap orang dengan sengaja dan tanpa hak mendistribusikan dan/atau mentransmisikan dan/atau membuat dapat diaksesnya Informasi Elektronik dan/atau Dokumen Elektronik yang memiliki muatan penghinaan dan/atau pencemaran nama baik.

Lebih lanjut dijelaskan dalam Pasal 45 ayat (1) bahwa setiap orangyang dengan sengaja dan tanpa bak mendistribusikan dan/atau mentransmisikan dan/atau membuat dapat diaksesnya Informasi Elektronik dan/atau Dokumen Elektronik yang memiliki muatan yang melanggar kesusilaan sebagaimana dimaksud dalam Pasal 27 ayat (1) dipidana dengan pidana penjara paling lama 6 (enam) tabun dan/atau denda paling banyak. Rp.1.000.000.000,00 (satu milyar rupiab).

Serta dalam Pasal 52 ayat (1) dijelaskan pula bahwa dalam hal tindak pidana sebagaimana dimaksud dalam Pasal 27 ayat (1) menyangkut kesusilaan atau eksploitasi seksual terbadap anak dikenakan pemberatan sepertiga dari pidana pokok.

\section{Pasal 52 ayat (4)}

Dalam Undang-Undang Informasi dan Transaksi Elektronik Pasal 52 ayat (4) dijelaskan bahwa Dalam hal tindak pidana sebagaimana dimaksud dalam Pasal 27 dilakukan oleh korporasi dipidana dengan pidana pokok ditambah dua pertiga.

Pasal 27 yang dimaksud dalam pembahasan ini dikhususkan pada Pasal 27 ayat (1)

d. Undang-Undang Nomor 21 Tahun 2007 tentang Pemberantasan Tindak Pidana Perdagangan Orang

Tindak pidana eksploitasi seksual anak diatur pula dalam undang-undang ini dan pengaturannya terdapat dalam pasal:

\section{Pasal 2}

Dalam Undang-Undang Pemberantasan Tindak Pidana Perdagangan Orang Pasal 2 ayat (1) dijelaskan bahwa setiap orang yang melakukan perekrutan, pengangkutan, penampungan, pengiriman, pemindahan, atau penerimaan seseorang denga ancaman kekerasan, penggunaan kekerasan, penculikan, penyekapan, pemalsuan, penipuan, penyalahgunaan kekuasaan atau posisi rentan, penjeratan utang atau memberi bayaran atau manfaat walaupun memperoleh persetujuan dari orang yang memegang kendali atas orang lain, untuk tujuan mengeksploitasi orang tersebut di wilayah negara Republik Indonesia, dipidana dengan pidana penjara paling singkap 3 (tiga) tabun dan paling lama 15 (lima belas) tabun 
KRTHA BHAYANGKARA | Volume 15 Number 2, December 2021

dan pidana denda paling sedikit Rp. 120.000.000,00 (seratus dua pulub juta rupiah) dan paling banyak Rp.600.000.000,00 (enam ratus juta rupiah).

Lebih lanjut dalam Pasal 2 ayat (2) diatur bahwa jika perbuatan sebagaimana dimaksud pada ayat (1) mengakibatkean orang tereksploitasi, maka pelaku dipidana dengan pidana yang sama sebagaimana dimaksud pada ayat (1).

\section{Pasal 5}

Dalam Undang-Undang Pemberantasan Tindak Pidana Perdagangan Orang Pasal 5 ini dijelaskan bahwa setiap orang yang melakukan pengangkatan anak dengan menjanjikan sesuatu atau memberikan sesuatu dengan maksud untuk dieksploitasi dipidana dengan pidana penjara paling singkat 3 (tiga) tabun dan paling lama 15 (lima belas) tabun dan pidana paling sedikit Rp. 120.000.000,00 (seratus dua pulub juta rupiab) dan paling banyak R. 600.000.000,00 (enam ratus juta rupiah)

\section{Pasal 6}

Pasal 6 Undang-Undang Pemberantasan Tindak Pidana Perdagangan Orang ini menjelaskan bahwa setiap orang yang melakukan pengiriman anak ke dalam atau ke luar negeri dengan cara apapun yang mengakibatkan anak tersebut tereksploitasi dipidana dengan pidana penjara paling singkat 3 (tiga) tahun dan paling lama 15 (lima belas) tahun dan pidana denda paling sedikit Rp. 120.000.000,00 (seratus dua pulub juta rupiab) dan paling banyak R. 600.000.000,00 (enam ratus juta rupiah).

\section{Pasal 7}

Dalam Pasal 7 disebutkan ayat (1) dan ayat (2) menjelaskan bahwa apabila tindak pidana yang dilakukan sebagaimana Pasal 2, Pasal 3, Pasal 5, Pasal 5 dan Pasal 6 mengakibatkan korban menderita luka berat, gangguan jiwa berat, penyakit menular lainnya yang membahayakan jiwanya, kehamilan, atau terganggu atau hilangny a fungsi reproduksinya, maka ancaman pidananya ditambah 1/3 (sepertiga) dari ancaman pidananya dan apabila mengakibatkan matinya korban, dipidana dengan pidana penjara paling singkat 5 (lima) tahun dan paling lama penjara seumur bidup dan pidana denda paling sedikit Rp.200.000.000,00 (dua ratus juta rupiah) dan paling banyak R. 5.000.000.000,00 (lima milyar rupiah). 
KRTHA BHAYANGKARA | Volume 15 Number 2, December 2021

\section{Pasal 9}

Dalam Pasal 9 dijelaskan bahwa setiap orangyang berusaba menggerakekan orang lain supaya melakukan tindak pidana perdagangan orang dan tindak pidana itu tidak terjadi, dipidana dengan pidana penjara paling singkat 1 (satu) tahun dan paling lama 6 (enam) tabuan dan pidana denda paling sedikit Rp.40.000.000,00 (empat pulub juta) dan paling banyak Rp. 240.000.000,00 (dua ratus empat puluh juta rupiah).

\section{Pasal 10}

Pasal 10 undang-undang ini mengemukakan bahwa setiap orang yang membantu atau melakukan percobaan untuk melakukan tindak pidana perdagangan orang, dipidana dengan pidana yang sama sebagaimana dimaksud dalam Pasal 2, Pasal 3, Pasal 4, Pasal 5 dan Pasal 6.

\section{Pasal 12}

Dalam Undang-Undang Pemberantasan Tindak Pidana Perdagangan Orang, Pasal 12 menjelaskan bahwa setiap orangyang menggunakan atau memanfaatkan korban tindak pidana perdagangan orang dengan cara melakukan persetububan atau perbuatan cabul lainnya dengan korban tindak pidana perdagangan orang, mempekerjakan korban tindak pidana perdagangan orang untuk meneruskan praktik eksploitasi, atau mengambil keuntungan dari hasil tindak pidana perdagangan orang dipidana dengan pidana yang sama sebagaimana dimaksud dalam Pasal 2, Pasal 3, Pasal 4, Pasal 5 dan Pasal 6.

\section{e. Undang-Undang Nomor 39 Tahun 1999 tentang Hak Asasi Manusia}

Dalam undang-undang ini terdapat pasal-pasal yang mengatur mengenai tindak pidana eksploitasi seksual anak, yaitu:

\section{Pasal 64}

Dalam Pasal 64 dijelaskan bahwa setiap anak berhak untuk memperoleh perlindungan dari kegiatan eksploitasi ekonomi dan setiap pekerjaan yang membahayakan dirinya, sehingga dapat mengganggu pendidikan, kesehatan fisik, moral, kehidupan sosial, dan mental spiritualnya.

\section{Pasal 65}

Pasal 65 undang-undang ini menjelaskan bahwa setiap anak berbak untuk memperoleh perlindungan dari kegiatan eksploitasi dan pelecehan seksual, penculikan, 
KRTHA BHAYANGKARA | Volume 15 Number 2, December 2021

perdagangan anak, serta dari berbagai bentuk penyalahgunaan narkotika, psikotropika dan zat adiktif lainnya.

\section{f. Undang-Undang Nomor 44 Tahun 2008 tentang Pornografi}

Undang-Undang ini pun turut mengatur mengenai tindak pidana eksploitasi seksual anak. Pengaturan untuk tindak pidana ini terdapat dalam pasal:

\section{Pasal 4 ayat (1) jo Pasal 11 jo Pasal 37}

Pasal 4 menjelaskan bahwa:

Setiap orang dilarang memproduksi, membuat, memperbanyak, menggandakan, menyebarluaskan, menyiarkan, mengimpor, mengekspor, menawarkan, memperjualbelikan, menyewakan atau menyediakan pornografi secara eksplisit memuat persenggamaan, termasuk persenggamaan yang menyimpang, kekerasan seksual, masturbasi atau onani, ketelanjangan atau tampilan yang mengesankan ketelanjangan, alat kelamin, atau pornografi anak.

Pasal ini kembali ditegaskan dalam Pasal 11 yang menyatakan bahwa setiap orang dilarang melibatkan anak dalam kegiatan dan/atau sebagai obyek sebagaimana dimaksud dalam Pasal 4.

Lebih lanjut dalam Pasal 29 bahwa

Setiap orang yang melakukan perbuatan sebagaimana Pasal 4 ayat (1) dipidana dengan pidana penjara paling singkat 6 (enam) bulan dan paling lama 12 (dua belas) tabun dan / atau denda paling sedikit Rp.250.000.000,00 (dua ratus lima puluh juta rupiah) atau paling banyak Rp. 6.000.000.000,00 (enam milyar).

Sesuai Pasal 37 apabila melakukan perbuatan sebagaimana Pasal 11 dipidana dengan pidana yang sama dengan pidana sebagaimana dimaksud dalam Pasal 29 ditambah 1/3 (sepertiga) dari maksimum ancaman pidananya.

\section{Pasal 40 ayat (1)}

Dalam Pasal 40 ayat (1) ini dijelaskan bahwa dalam hal tindak pidana pornografi dilakukan oleh atau atas nama suatu korporasi, tuntutan dan penjatuhan pidana dapat dilakukan terbadap korporasi dan/ atau pengurusnya.

Lebih lanjut dalam Pasal 40 ayat (7) bahwa selain pidana penjara dan denda terbadap pengurusnya, dijatubkan pula pidana denda terhadap korporasi dengan ketentuan maksimum pidana dikalikan 3 (tiga) dari pidana denda yang ditentukan dalam setiap pasal dalam Bab ini.

Selain itu juga dalam Pasal 41 disebutkan bahwa selain pidana pokok sebagaimana dimaksud dalam Pasal 40 ayat (7), korporasi dapat dikenai pidana tambahan berupa pembekuan izin usaha, 
pencabutan izin usaha, perampasan kekayaan hasil tindak pidana, dan pencabutan status badan bukum.

\section{KESIMPULAN}

Tindak pidana eksploitasi seksual anak merupakan suatu bentuk kejahatan terorganisir yang biasanya dilakukan oleh orang-orang yang memiliki kekuatan dan kuasa. Tindak pidana eksploitasi seksual anak berbeda dengan tindak pidana kekerasan seksual pada anak, baik dalam bentuk kasus maupun penanganannya. Hingga saat ini, Indonesia belum memiliki peraturan perundang-undangan yang khusus mengatur masalah tindak pidana eksploitasi seksual anak. Peraturan perundangan yang ada hanya memasukkan TPESA secara terpisah sebagai bagian dari peraturan perundangan pidana lainnnya, seperti: (1) Undang-Undang Perlindungan Anak; (2) Undang-Undang Penghapusan Kekerasan Dalam Rumah Tangga; (3) Undang-Undang Informasi dan Transaksi Elektronik; (4) Undang-Undang Tindak Pidana Perdagangan Orang; (5) Undang-Undang Hak Asasi Manusia dan (6) Undang-Undang Pornografi.

\section{Saran}

Dalam upaya penanggulangan tindak pidana eksploitasi seksual anak diharapkan di masa yang akan datang akan ada peraturan perundang-undangan yang spesifik sebagai dasar bagi aparat penegak hukum dalam mengungkap dan menindak para pelaku tindak pidana ini. Lebih lanjut sebagai upaya penanggulangan, diharapkan kerjasama baik dari aparat penegak hukum, dinas terkait maupun masyarakat dalam mengungkap dan menangani berbagai bentuk kasus dan modus yang digunakan oleh pelaku dalam tindak pidana eksploitasi anak. Dalam penegakan hukum terhadap tindak pidana eksploitasi anak ini, diharapkan aparat penegak hukum mengedepankan perlindungan dan pemenuhan hakhak terhadap korban serta memberikan hukuman yang maksimal kepada pelaku sesuai dengan ketentuan yang berlaku.

\section{DAFTAR PUSTAKA}

\section{Buku}

Abdussalam R. Hukum Perlindungan Anak. Jakarta: PTIK. 2016

Arif Gosita. Masalah Perlindungan Anak. Jakarta: Pressindo. 1989 
KRTHA BHAYANGKARA | Volume 15 Number 2, December 2021 Masalab Korban Kejahatan. Jakarta: Pressindo. 2009

Bambang Waluyo. Viktimologi Perlindungan Saksi dan Korban. Jakarta: Sinar Grafika. 2011

Dikdik M. Arif. Urgensi Perlindungan Korban Kejahatan. Jakarta. 2007

ECPAT Internasional. Tanya Jawan Tentang Eksploitasi Seksual Komersial Anak. 2001 . Eksploitasi Seksual Anak Online: Sebuah Pemahaman Bersama.

Terjemahan. 2017

ELSAM. Seri Baban Bacaan Kursus HAM Untuk Pengacara XI Tabun 2007: Materi Konvensi Hak Anak. $\quad$ http://lama.elsam.or.id/downloads/126285403920 $\underline{\text { Kovensi Hak Anak.pdf }}$

I Dewa Made Suartha. Laporan Akbir Pengkajian Hukum Lembaga Penempatan Anak Sementara. Jakarta: Kementerian Hukum dan HAM Republik Indonesia. 2013 IOM Migrant Trafficking and Human Smuggling in Europe.Geneva. 2000. Lihat juga United Nations Office on Drugs and Crime. FAQ on Trafficking in Human Beings. 2005 James, B. Treating Traumatised Children. New Insights \& Creative Interventions. Lexington. 1969

Kamerman, S., Philips, S., \& Ben-Arieh A. (Eds). From Child Welfare to Child Well-Being: An International Perspective on Knowledge in the Service of Policy Making. Vol 1. Springer Science\&Business Media. 2009

Komisi Nasional Penghapusan Eksploitasi Seksual Komersial Anak. Eksploitasi Seksual Komersial Anak di Indonesia. Medan. 2008

Komisi Nasional Penghapusan Eksploitasi Seksual Komersial Anak. Memerangi Pariwisata Sex

Anak: Tanya dan Jawab. Medan. 2008

Leden Marpaung. Kejahatan Terbadap Kesusilaan dan MasalabPrevensinya. Jakarta: Sinar Grafika. 2008

Maidin Gultom. Perlindungan Hukum Terbadap Anak. Bandung: Refika Aditama. 2014 Perlindungan Hukum Terbadap Anak dan Perempuan. Bandung: Refika

Aditama. 2013

P.A.F. Lamintang. Delik-Delik Khusus Kejahatan Melanggar Norma Kesusilaan dan Norma 
KRTHA BHAYANGKARA | Volume 15 Number 2, December 2021

Kepatutan. Jakarta: Sinar Grafika. 2009.

Rena Yulia. Viktimologi Perlindungan Hukum Terbadap Korban Kejahatan. Yogyakarta: Graha Ilmu. 2010

Wigiati Soetodjo. Hukum Pidana Anak. Bandung: Refika Aditama. 2006

\section{Peraturan Perundang-Undangan}

Republik Indonesia. Undang-Undang Nomor 39 Tahun 1999 tentang Hak Asasi Manusia

Republik Indonesia. Undang-Undang Nomor 23 Tahun 2004 tentang Penghapusan Kekerasan

Dalam Rumah Tangga.

Republik Indonesia. Undang-Undang Nomor 44 Tahun 2008 tentang Pornografi

Republik Indonesia. Undang-Undang Nomor 21 Tahun 2007 tentang Pemberantasan Tindak

Pidana Perdagangan Orang

Republik Indonesia. Undang-Undang Nomor 11 Tahun 2008 tentang Informasi dan Transaksi

Elektronika

Republik Indonesia. Undang-Undang Nomor 35 Tahun 2014 tentang Perubahan Atas Undang-

Undang Nomor 23 Tahun 2002 tentang Perlindungan Anak

Republik Indonesia. Peraturan Pemerintah Nomor 2 Tahun 2018 tentang Standar Pelayanan Minimum

Republik Indonesia. Peraturan Pemerintah Nomor 39 Tahun 2012 tentang Penyelenggaraan Kesejahteraan Sosial

Republik Indonesia. Peraturan Menteri Sosial Nomor 7 Tahun 2017 tentang Standar Habilitasi dan Rehabilitasi Sosial Penyandang Disabilitas

\section{Jurnal, Makalah, Artikel}

Aidy, W. R. (2020). Perlindungan Hukum Terhadap Anak Yang Berkonflik Dengan Hukum. Jurnal Hukum Sasana, 5(1). https://doi.org/10.31599/sasana.v5i1.90

Al Adawiah, R. (2019). Child Abuse Dan Keamanan Lingkungan Anak Dalam Menyongsong Bonus Demografi 2025-2030. Krtha Bhayangkara, 13(1). https://doi.org/10.31599/krtha.v13i1.13 
Putri, A. H., \& Irsan, K. (2019). Penanganan Polisi Terhadap Kasus Perdagangan Perempuan Dan Anak Di Kalimantan Dan Jawa. Krtha Bhayangkara, 13(1). https://doi.org/10.31599/krtha.v13i1.20

Irwanto. Anak Sebagai Saksi Korban. http://ecpatindonesia.org/berita/anak-sebagai-saksikorban/

Sofian, Ahmad. Transformasi Hukum Tindak Pidana Eksploitasi Seksual Anak. 2017

http://businesslaw.binus.ac.id/2017/02/28/ transformasi-hukum-tindak-pidana-

eksploitasi-seksual-anak

DPR Ratifikasi Protokol Opsional Hak-Hak Anak.

http://kemlu.go.id/layouts/mobile/PortalDetailNewsLike.aspx?1=id\&ItemID=b46912 44-2eb4-4ec0-9ef8-b3665f9441d6

Introduction to the Convention on the Rights of the Child: Definition of Key Terms.

http://www.unicef.org/crc/files/Definitions.pdf

Konvensi Hak Anak

http://bappeda.kendalkab.go.id/index.php?option $=$ com

$\underline{\text { content } \& \text { view }=\text { article } \& \text { catid }=29}$ :pemsosbud $\& \mathrm{id}=87$ :konvensi-hak-hak-anak

Definition of Key Terms Used in the UN Treaty Collection

http://treaties.un.org/Pages/Overview.aspx?path=overview/definition/page1 en.xml.

Introduction to the Convention of the Rights of the Child: Definition of Key Terms

http://www.unicef.org/crc/Definitions.pdf. 
KRTHA BHAYANGKARA | Volume 15 Number 2, December 2021 